\title{
Epidemiological study with the mare and Neotyphodium coenophialum toxins
}

\author{
F. F. FANNIN, D. KUBLY, Y. WANG and L.P. BUSH \\ Department of Plant and Soil Sciences, University of Kentucky, Lexington, KY 40546-0312 USA \\ lpbush@uky.edu
}

\begin{abstract}
The objective of this study was to relate chemical components of pastures containing tall fescue suspected to be causative to reduced conception and early embryonic death in the mare. Pasture sampling was conducted on 143 pastures and over 500 sites during mare breeding. Tall fescue was $16-42 \%$ of the forage in most pastures and about $65 \%$ of the plants were infected with Neotyphodium coenophialum. Ergovaline content ranged from 0 to $2220 \mathrm{ng} / \mathrm{g}$. Lysergic acid was present in equal or lesser amounts than ergovaline. Approximately $10 \%$ of the mares did not conceive or had early foetal loss. Because of other components in the diet, a direct cause/effect relationship cannot be made between mare response and $N$. coenophialum related toxins. These results suggest that a large number of animals will be required when designing an experiment to show how tall fescue might affect reproduction in mares.
\end{abstract}

Keywords: horse pastures, alkaloids, minerals

\section{Introduction}

Pasture quality has made central Kentucky the centre of the thoroughbred breeding industry in the USA. In 2004, 34\% (20 176 thoroughbred mares) of all thoroughbred mares bred in North America were in Kentucky. A long standing enigma that has concerned veterinarians and farm managers is the random occurrence of dramatic drops in conception rates and sudden rises in early embryonic death (EED) in reproductively healthy mares during the breeding season. Clinical impression is that seasonal changes in pasture grasses contribute to the pregnancy losses. Little is known about the effects of seasonal changes in pasture content on reproductive efficiency, even though pasture grasses can constitute up to $60-80 \%$ of the total intake of food stuffs by broodmares (Lewis 1995).

Tall fescue [Festuca arundinacea Schreb. = Lolium arundinaceum (Schreb.) SJ Darbyshire = Schedonorus phoenix (Scop.) Holub] is commonly used for forage and turf purposes in Kentucky. Approximately 2.2 million hectares are grown in Kentucky and are grazed by an estimated 200000 horses and/or ponies per year (KEEP 2005). Despite its good nutritive value, consumption of tall fescue by livestock results in decreased reproductive performance and growth. It has been found that animal performance was depressed due to an endophytic fungus (Neotyphodium coenophialum) (review Bush et al. 1979). Primary classes of alkaloids produced by the fungus and that may play a role in affecting animal performance are the ergot (ergovaline) and unsaturated pyrrolizidine (lolines) alkaloids.

Prolonged gestation, agalactia, increased foal and mare mortality, dystocia, tough and thickened placentas, weak and dysmature foals, reduced serum progesterone and prolactin, and increased serum estradiol $17-\beta$ are all signs commonly associated with mares consuming endophyte-infected fescue (Porter \& Thompson 1992). During a 60 day breeding period Brendemuehl et al. (1994) found mares grazing endophyte-infected (1200 vs $30 \mathrm{ng} / \mathrm{g}$ ergovaline) tall fescue had prolonged luteal function (22.9 vs. 15.8 days) and higher embryonic death (30\% vs. $7.7 \%$, respectively) than mares grazing endophyte-free tall fescue pastures. Serum progesterone and prolactin concentrations were lowered by the higher ergovaline containing treatment. However, Arns et al. (1997) fed a tall fescue seed-based diet containing three levels of ergovaline $(0,160$ and $320 \mathrm{ng} / \mathrm{g})$ to mares and measured lower serum progesterone and prolactin levels but with no effect on overall conception rates, cycles per conception or embryonic vesicle size through 28 days of pregnancy. Ryan et al. (2001) demonstrated that systemic relaxin was higher in mares grazing tall fescue treated with fluphenazine than controls and gestation time was shortened. In a short study (Youngblood et al. 2005), mares fed endophyte infected tall fescue seed as a portion of their diet for 10 days during days 65 to 100 of gestation had significantly greater urinary ergot alkaloid concentration for the next 21 days but no foetal loss occurred. However, ergovaline levels were only $135 \mathrm{ng} / \mathrm{g}$ in the feed plus $45 \mathrm{ng} / \mathrm{g}$ in the $\mathrm{ad}$ libitum hay. These levels are below the suspected threshold for activity in the mare. Even so, plasma 3, 4-dihydroxyphenyl acetic acid concentration decreased suggesting an impact on the endocrine system. Taken as a whole these results suggest that total exposure may be as important as an acute bolus of toxin on mare response. Schultz et al. (2006) did not detect ergovaline in urine of geldings but $35-40 \%$ of ergovaline consumed was found in the faeces. Lysergic acid was excreted in urine and faeces in greater amounts than ingested suggesting metabolism of ergot alkaloids to lysergic acid in the horse. Klotz et al. (2006) did not demonstrate a contractile response of bovine saphenous vein below $10^{-4} \mathrm{M}$ lysergic acid, whereas ergovaline stimulated vasoconstriction at $10^{-8} \mathrm{M}$.

Ergovaline levels used in the experiments of Arns et al. (1997), Ryan et al. (2001) and Youngblood et al. (2004) were much below the levels found in preliminary studies in Kentucky thoroughbred pastures in the last 3 years. Concentrations ranged from 0.0 to $1555 \mathrm{ng} / \mathrm{g}$, with an average concentration of $300 \mathrm{ng} / \mathrm{g}$, with at least 45 days of over $1000 \mathrm{ng} / \mathrm{g}$ for a maximum average. By May 1 2004, we measured over 1000 ng/g at several sites within thoroughbred pastures and the farm maximum average remained above 1000 until early winter (Schultz \& Bush 2003). Hovermale \& Craig (2001) suggested 300 to $500 \mathrm{ng} / \mathrm{g}$ ergovaline in the diet would negatively affect reproductive efficiency in mares Cornell et al. (1990) reported that as little as $50 \mathrm{ng} / \mathrm{g}$ of ergovaline is sufficient to produce symptoms of fescue toxicity in cattle under heat stress conditions. Based upon transport potential across gastric tissues, lysergic acid or lysergol may be the toxin arriving at the tissue (Hill et al. 2001). If this hypothesis is correct and that much of the lysergic acid detected in the animal comes from degradation of ergopeptine alkaloids, the amount of ergovalinine must be considered along with the amount of ergovaline present in tall fescue forage. From our preliminary results, the amount of ergovalinine is a large portion (35\%) of the ergopeptine alkaloids present and must be considered a potential toxin.

\section{Methods and Experimental Design}

Pastures for this study were on thoroughbred farms in central Kentucky with over 700 mares available to follow conception and pregnancy response. Pastures were sampled frequently from about March 1 to July 1 from up to six sites within each pasture with each site representing approximately 2.4-3.2 hectares. Amount of weeds, tall fescue and other grasses were visually 
Figure 1 Illustrates the accumulation of minerals and alkaloids averaged over eight pastures from one farm.

\section{Fig 1A}

\section{Phosphorus, Calicum and Magnesium Farm I}

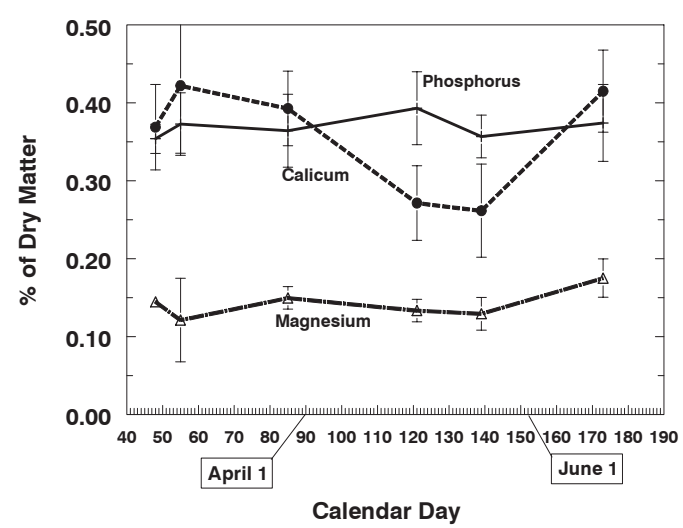

Fig 1C

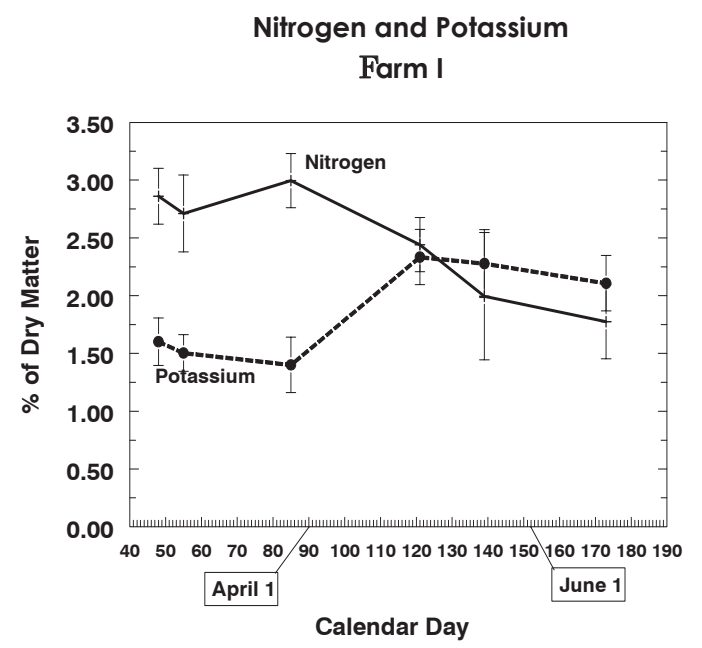

evaluated for each pasture. Visual ratings were ground-validated by digital measurements and grid sampling of the image. Percent of tall fescue infected with the endophyte in each pasture was determined after mid-May. At least 100 tall fescue tillers per pasture, representative of each site within a pasture, were sampled for immunoblot analysis for presence of the fungal endophyte (Gwinn et al. 1991).

Dried plant materials was powdered and analysed for (a) ergovaline, ergovalinine and lysergic acid by HPLC with a fluorescence detector by a modified procedure of Yates \& Powell (1988), (b) loline alkaloids by a modified GC procedure of Kennedy \& Bush (1983), (c) N as Kjeldahl N (short method, did not include $\mathrm{NO}_{3}-\mathrm{N}$ ), (e) P colorimetrically and (f) $\mathrm{Ca}$ and $\mathrm{K}$ with atomic absorption spectroscopy following wet ashing
Fig 1B

\section{$\mathrm{K} / \mathrm{Ca}$ and $\mathrm{Ca} / \mathrm{P}$ ratios Farm I}

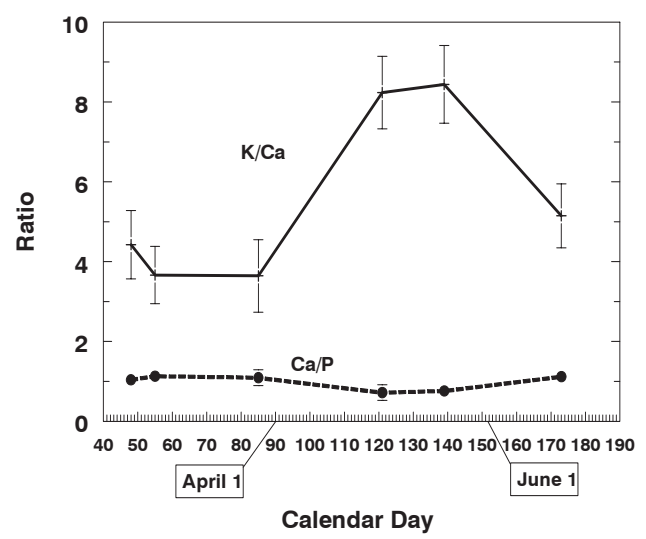

Fig 1D

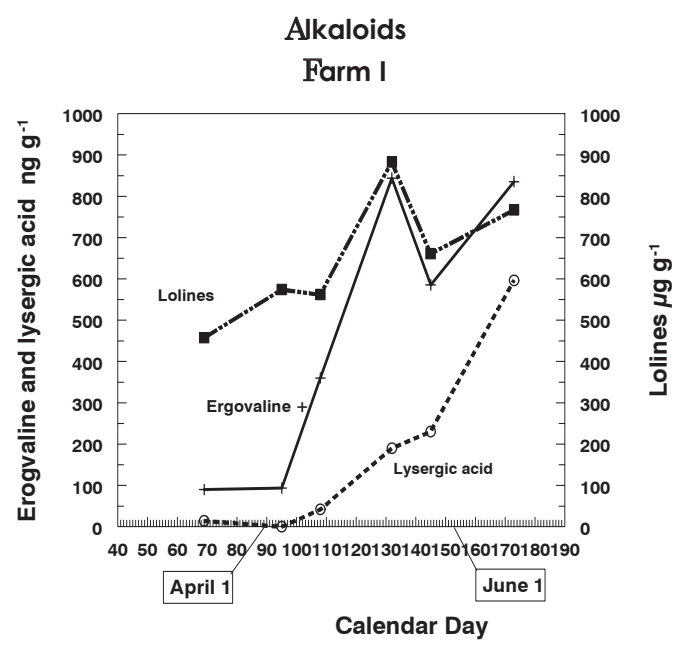

\section{Results}

Botanical composition of the pastures was determined in late winter and late spring. Bluegrass, orchard grass and tall fescue comprised about $80-85 \%$ ground-cover of the herbage. Tall fescue was $30-45 \%$ of the herbage in most pastures but occasionally exceeded $70 \%$ of the herbage. In pastures with lesser amounts of tall fescue, there was usually a significant increase in white clover, from less than $1 \%$ to $10-15 \%$ of the herbage. Of the tall fescue present $70-80 \%$ of the tillers were infected with $N$. coenophialium. The portion of herbage in a pasture that was tall fescue tended to increase from late winter to early spring. This was probably due to greater growth than the other cool-season grasses as temperatures increased during transition from winter to early spring. Data presented in this paper are from tall fescue 
herbage only and for simplicity from eight pastures on one farm.

Mineral composition of the tall fescue herbage generally met the suggested equine daily intake values for first 9 months of gestation (Briggs 1998). Phosphorus values were above the suggested value, magnesium levels were at the lower end of the suggested range and calcium values were below the suggested range during days about 30-50 of gestation (Fig 1A). Thus $\mathrm{Ca} /$ $\mathrm{P}$ ratios were approximately $10-30 \%$ below suggested values of 1.2-1.6 (Fig 1C). Potassium levels were 2-4 times higher that suggested intake values and increased with increased ambient and soil temperatures (Fig $1 \mathrm{~B}$ ). $\mathrm{K} / \mathrm{Ca}$ ratios were very high in these samples.

Pyrrolizidine (frequently referred to as loline alkaloids) levels averaged 100 to $850 \mu \mathrm{g} / \mathrm{g}$ with highest levels of over $1750 \mu \mathrm{g} / \mathrm{g}$ in these pastures (Fig 1D). The highest total pyrrolizidine level measured from all the pastures in the study was over $2800 \mu \mathrm{g} / \mathrm{g}$. As expected about two-thirds of the pyrrolizidine alkaloids were $\mathrm{N}$-formylloine, about $25 \% \mathrm{~N}$-acetylloline and less than $10 \% \mathrm{~N}$ acetyl norloline. During the sampling period ergovaline averaged from $70-825 \mathrm{ng} / \mathrm{g}$ in these pastures with a study maximum of $2220 \mathrm{ng} / \mathrm{g}$. The lower values were measured in early spring and increased during time of normal inflorescence development. Pastures were maintained at $20-30 \mathrm{~cm}$ herbage height and though heading was not observed some development probably occurred. Ergovalinine had a very similar pattern of accumulation with an average of 19-328 $\mathrm{ng} / \mathrm{g}$ and a study maximum of $1450 \mathrm{ng} /$ g. Early in the growing season ergovaline was more than three times the amount of ergovalinine but during the late spring and early summer this ratio was about 1.5. Lysergic acid content was lower than the ergovaline and ergovalinine but had a similar pattern of accumulation. Early in the growing season lysergic acid was $10 \%$ and increased to above $70 \%$ of the ergovaline + ergovalinine content by the end of June. The ergovaline content measured was often above the threshold cited for negative mare responses (Hovermale \& Craig 2001). If the ergovalinine and lysergic acid amounts are included, the amount of potential toxin present greatly exceeds the threshold. On these pastures there was a $6 \%$ loss of foals from over 100 mares and all but one loss was from the three pastures with the greatest ergovaline content. For the entire study over $10 \%$ of mares either aborted or did not become pregnant. This suggests that the ergot alkaloids plus lysergic acid have a large impact on both early embryonic death and late term foetal losses in the horse. Similar results were obtained from the other farms in this study. The small number of EED and additional covers required compared to "normal" reproduction of the mare, make it essential that large numbers of mares be included in these studies. Because tall fescue was often less than $50 \%$ of the herbage in the pasture and all the animals were receiving some concentrate feed, we must determine the tall fescue intake and thus the potential toxin intake, to make a definitive conclusion about attributing these losses to the tall fescue in the pasture.

\section{ACKNOWLEDGEMENTS}

The study was financed by a grant from Forage Animal Production Research Unit, ARS, USDA to LPB (58-6401-2-0025).

\section{REFERENCES}

Arns, M.J.; Pruitt, J.A.; Sharp, C. 1997. Influence of endophyteinfected tall fescue seed consumption on the establishment and maintenance of pregnancy in mares. Professional Animal Scientist 13: 118-123.
Brendemuehl, J. P.; Boosinger, T.R.; Pugh. D.G.; Shelby, R.A. 1994. Influence of endophyte-infected tall fescue on cyclicity, pregnancy rate and early embryonicloss in the mare. Theriogenology 42: 489-500.

Briggs, K. 1998. Understanding Equine Nutrition. Eclipse Press, Lexington, KY.Bush, L.P.; Boling, J.A.; Yates, S.G. 1979. Animal disorders. pp. 247-292. In: Tall fescue monograph. Eds. Buckner, R.C.; Bush, L.P. Society of Agronomy. Madison, WI.

Cornell, C.N.; Lueker, J.V.; Garner, G.B.; Ellis, J.L. 1990. Establishing ergovaline levels for fescue toxicosis, with and without endoparasites, under controlled climatic conditions. p. 75. In: Proceeding of International Symposium on Acremonium/Grass interactions. Eds. Quisenberry, S.S.; Joost, R.E. Louisiana Agricultural Experiment. Station.

Gwinn, K.D.; Shepard-Collins, M.H.; Reddick, B.B. 1991. Tissue print-immunoblot: an accurate method for the detection of Acremonium coenophialum in tall fescue. Phytopathology 81 : 747-748.

Hill, N.S.; Thompson, F.N.; Stuedemann, J.A.; Rottinghaus, G.W.; Ju, H.J.; Dawe, D.L.; Hiatt, E.E. 2001. Ergot alkaloid transport across ruminant gastric tissues. Journal Animal Science 79: 542-549.

Hovermale, J.T.; Craig, A.M. 2001. Correlation of ergovaline and lolitrem B levels in endophyte-infected perennial ryegrass (Lolium perenne). Journal Veterinary Diagnostic Investigation 13: 323-327. KEEP. 2005. www.horseswork. com/economy.php

Kennedy, C.W.; Bush, L.P. 1983. Effect of environment and management factors on the accumulation of $\mathrm{N}$-formyl loline alkaloids in tall fescue. Crop Science 23: 547-552.

Klotz, J.L.; Bush, L.P.; Smith, D.L.; Shafer, W.D.; Smith, L.L.; Vevoda, A.C.; Craig, A.M.; Arrington, B.C.; Strickland, J.R. 2006. Assessment of vasoconstrictive potential of D-lysergic acid using an isolated bovine lateral saphenous vein bioassay. Journal of Animal Science 84: 3167-3175.

Lewis, L.D. 1995. Equine Clinical Nutrition:Feeding and Care. Williams and Willins. Media, PA.

Porter, J. K.; Thompson, F.N. 1992. Effects of fescue toxicosis on reproduction in livestock. Journal Animal Science 70: 1594-1603.

Ryan, P.L.; Bennett-Wimbush, K.; Vaala, W.E.; Bagnell, C.A. 2001. Systemic relaxin in pregnant pony mares grazed on endophyte infected fescue: effects of fluphenazine treatment. Theriogenology 56: 471-483.

Schultz, C.L.; Bush, L.P. 2003. The potential role of ergot alkaloids in marae reproductive low syndrome. pp 60-63. In: Proceedings of the first workshop on mare reproductive loss syndrome. Eds. Powell, D.G.; Troppman, A.; Tobin, T. Kentucky Agricultural Experiment Station.

Schultz, C.L.; Lodge-Ivey, S.L.; Bush, L.P.; Craig, A.M.; Strickland, J.R. 2006. Effects of initial and extended exposure to endophyte-infected tall fescue seed diet on faecal and urinary excretion of ergovaline and lysergic acid in mature geldings. New Zealand Veterinary Journal 54: 178-184.

Yates, S.G.; Powell, R.G. 1988. Analysis of ergopeptine alkaloids in endophyte-infected tall fescue. Journal Agriculture Food Chemistry 36: 337-340.

Youngblood, R.C.; Filipov, N.M.; Rude, B.J.; Christiansen, D.L.; Hopper, R.M.; Gerard, P.D.; Hill, N.S.; Fizgerald, B.P.; Ryan, P.L. 2004. Effects of short-term early gestational exposure to endophyte-infected tall fescue diets on plasma 3, 4dihydrozyphenyl acetic acid and fetal development in mares. Journal Animal Science. 82: 2919-2929. 